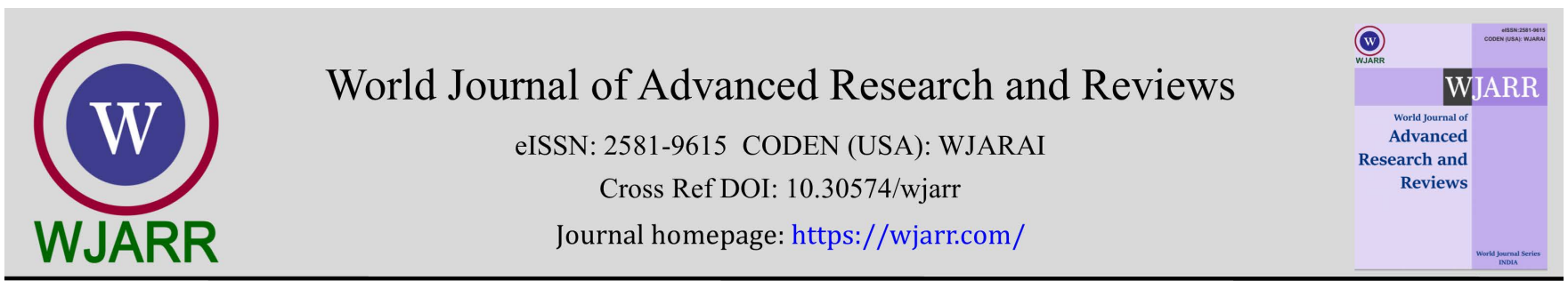

(RESEARCH ARTICLE)

\title{
New dendroclimatological research in oak, S (Quercus Frainetto Ten.) forestry in Šumadija-Region- (Central Serbia) as a basis for climate change monitoring
}

\author{
Severin Šikanja * and Nevena Milovanović \\ Metropolitan university-Belgrade Faculty for applied ecology Futura.
}

World Journal of Advanced Research and Reviews, 2021, 11(02), 249-259

Publication history: Received on 23 June 2021; revised on 18 August 2021; accepted on 20 August 2021

Article DOI: https://doi.org/10.30574/wjarr.2021.11.2.0292

\begin{abstract}
In this work present study to describe the survey of climatic change in the case in Šumadija-Central Serbia. Climate change due to a fragile ecosystem in semi-arid, and arid region such as Serbia is one of the most challenging climatological and hydrological problems. Dendrochronology, wich uses tree rings to their exact year of formation to analyse temporal and spatial patterns of processes in the physical and cultural sciences, can be used to evaluate the effects of climate change. In this study, the effects of climate change werw simulated using dendrochronology (tree rings) and an artificial neural network (ANN) for the period from 1900-2015. The present study was executed using the (Quercus frainetto Ten.). Tree rings width, temperature and precipitation were the input parameters for the study, and climate change parameters were the outputs. After the training process, the model was verified. The verified network and tree rings were used to simulate climatic parameter changes during the past times. The results showed that the integration of dendroclimatology and an ANN renders a high degree of accuracy and efficiency in the simulation of climatic change. The results showed that the climatic of the study area changed from semiarid, to arid, and its annual precipitation decreased significantly.
\end{abstract}

Keywords: Climate change; Tree rings; Quercus; Serbia

\section{Introduction}

Climate change refers to unexpected changes in the Earth,s climate,s characteristics that occur in the long-term [1]. Futher the forest in Earth, has important roles in runoff generation, soill erosion and climate conditions [2]. Increase in global temperature is the most obvious sign of this change [3] and therefore temperature variations are commonly used to detect and quantify possible changes in climate [4]. Also, climatologic, hydrologic and hydroecologic records are necessary for water resource planning and management. Plants grow in spring and summer seasons better than in autumn and winter. This mer season better than in autumn and winter. This provides the studies of climate change by annual growth rings of trees [5]. According to previous studies, there is a relatinshio between precipitation, temperature, and tree rings and can, therefore, be useful for developing long-term estimates of specific hydrological variables and also in chronology studies [6]. Dendrochronology is one of methods applied in reconstructing past environmental events. It is the science of defining past climatic and hydrologic variability from tree-rings data [7]. Due to the growth-limiting effects of low precipitation, and high temperatures, dendroclimatic (as one the branches of dendrochronology) studies would be successful in part [8]. Dendroclimatology is concerned with constructing records of past climates and climatic events by the analysis of tree growth characteristics and especially applied to reconstruct hydrologic variables such as river charge [9], studied the relationship between climates with the growth and death of Quercus frainetto Ten. - In the lowlands and uplands. Moreover, their results showed that precipitation has an important role in the forest and that the optimum depth to groundwater ranges from two to eight meters. In certain areas, soil moisture declines when precipitation decreases and when depth of groundwater increases [10]. Therefore, trees wil

\footnotetext{
${ }^{*}$ Corresponding author: Severin Šikanja

Metropolitan university-Belgrade Faculty for applied ecology Futura. 
produce wider annual rings in wet years compared to dry years. Therefore, tree rings and vessel features are valuble proxies in the evaluation of climatic changes, but it is important to select tree species that are suistable for dendroclimatology studies. We selected Quercus frainetto Ten. For dendroclimatology study in the Šumadija region, of central Serbia. Quercus frainetto Ten. is an important species native to Šumadija-region, and is a suitable selection for evaluating annual changes in climatic factors [11]. Quercus species is tha largest genus in the family Fagaceae with approximately (300-500 species) [12]. The sensitivity of the Quercus species tree-rings extent to climatological and water access changes is high. To find out the climate trend in a future course, we select a climate change forecating model using artificial neural network (ANN). In general different studies have indicated the usefulness of the ANN to simulate the climatic factors [13]. From these studies, it has been demonstraated that ANN models can be flexibile enough to simulate the climatic factors successfully. The goal of this study is the application of dendroclimatology in the evaluation of climate change effect by combining denroclimatology and ANN modeling to simulate the climatic factors.

\section{Material and methods}

\subsection{Study area}

The forest complex (study area) "Rogot"- Figure 1-farm unit extends between $44^{\circ} 05 \pitchfork$ and $44^{\circ} 09 \$$ north latitude and $18^{\circ} 37 \$$ and $18^{\circ} 47 \$$ east longitude. The farm unit "Rogot" is located in a relatively densely populated plain, partly near Velika Morava (one part), and for the most part the unit is followed by the Lepenica River with its numerous mountain streams and rivers. Otherwise, Sumadija is rich in rivers and streams, which contributes to the general state of hydrological conditions. The administrative unit Rogot is surrounded by the settlements Lapovo, Brzan, Dobrovodica, Badnjevac, Prnjavor, Žirovnica and Batocina. The Rogot Farm Unit has good road infrastructure, which is good when performing forest operations, the terrain is accessible and accessible to any department, making it much easier to get the trees out.

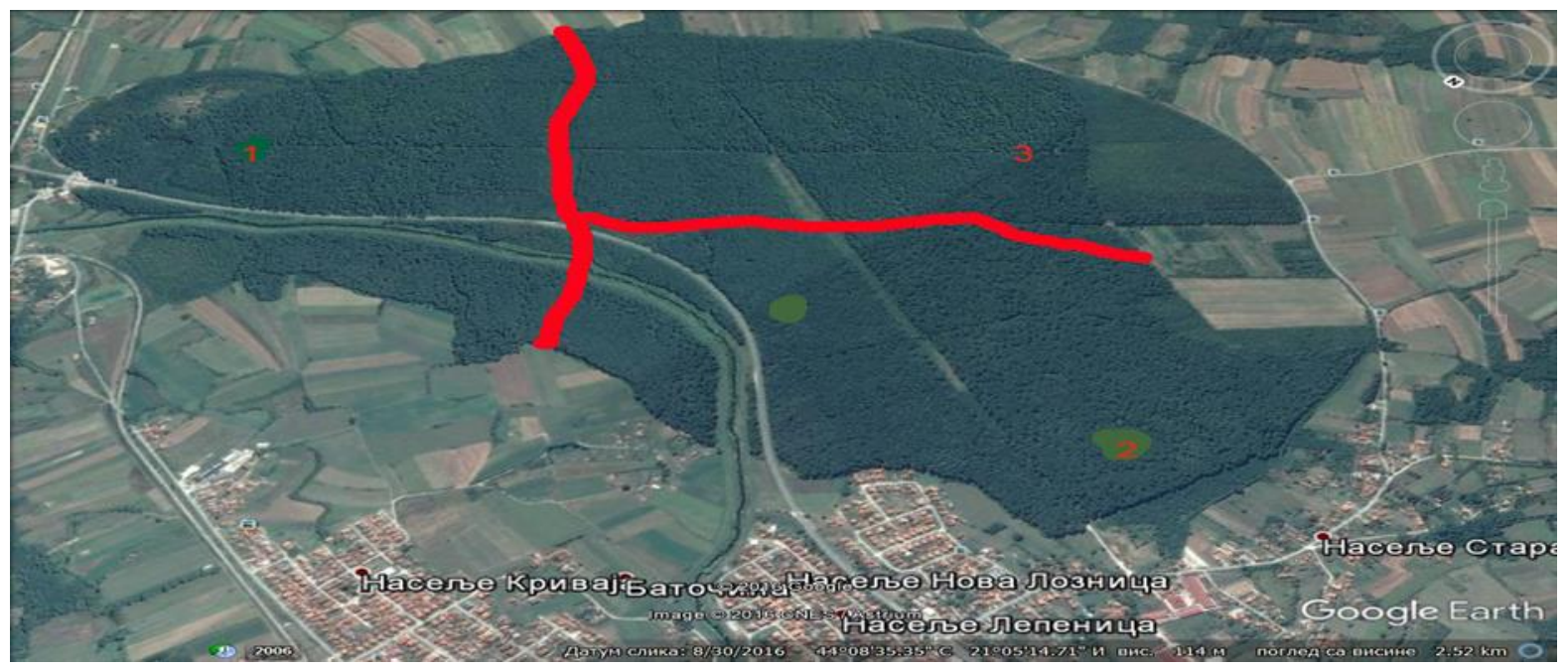

Figure 1 (Study area). 3 colored fields are displayed in red color. The borders between the test fields are also marked in red

\section{The most important climatic factors (precipitation and temperature) of the study area:}

Note: Data are from the official Kragujevac meteorological station - altitude $183 \mathrm{~m}$.

Climate is an important factor in soil pedogenesis and a limiting factor in the development of certain plant formations over temperature relationships, size and distribution of watercourses. The climate has a very strong effect on wildlife. It mainly determines the layout and structure of the plant cover. The effect of climate on wildlife is complex. Šmadija belongs to the Eastern Continental Region. The characteristics of this area are low annual rainfall, higher average summer temperatures, strong evaporation and low temperature winter. Here, however, the climate is slightly milder than it would correspond to a continental type that is clearly expressed in Vojvodina- (North region in Serbia). 


\subsection{Temperature}

The average maximum average temperature is " $17.05^{\circ} \mathrm{C}$ ". The average minimum temperature is " $8.15^{\circ} \mathrm{C}$ ". The normal value is " $12.2^{\circ} \mathrm{C}$ ". The absolute maximum is " $41.9^{\circ} \mathrm{C}$ ". The absolute minimum is " $19.2^{\circ} \mathrm{C}$ ".

\subsection{Precipitation}

By the mean annual rainfall this is undoubtedly the driest part of the area. The average annual rainfall is $600-700 \mathrm{~mm}$ $(681.9 \mathrm{~mm})$. However, in the valleys of the Greater and South Moravas it descends to $560 \mathrm{~mm}$. In the hilly areas alone, it exceeds just over $700 \mathrm{~mm}$ occasionally. The season with the highest rainfall is summer, and in the southern part it is spring, while the driest season in the whole region is winter.

\subsection{Dendroclimatology studies in research area}

In order to reconstruct the climate of the past, tree rings are evaluted for their full length using statistical models. We collected 30 samples from the old trees. The longest tree -ring series covered 115 years, extending back 1900-2015 year. Two cores were extracted at breast height in the vertical directions $(130 \mathrm{~cm})$. We provided a suitable box for core conservation. Sanding of the cores was done until the tree-rings extent was clearly visible.

\subsection{Crossdating and standardization}

Crossdating can be described as the recognition of same tree ring pattern in a species with different stands, as the actual grouth date of any one ring of pattern is the same in the different trees, and one may carry a chronology across from tree to tree [14]. The crossdating process is done by measuring the extent of annual tree rings. The tree-rings extents of the smples were arranged according to their cambial age (the number of rings from the centre). At first, crossdating was performed by matching tree ring patterns (wide and narrow rings) using th skeleton plot method [15]. Cores were visually crossdated against the estabished record using the signature patterns of ring width. [16]. This is a non-climate variance when the process of its modelling, approximating and removing is known as standardization [17]. The standardized tree-rings index was based on:

$$
\mathrm{I}_{\mathrm{t}}=\mathrm{W}_{\mathrm{t}} / \mathrm{Y}_{\mathrm{t}}
$$

where $\mathrm{I}_{\mathrm{t}}$-standardizedcctree ring index.

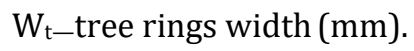

Yt-estimated growth curve for yeart.

We used a regression relationship and $\mathrm{I}_{\mathrm{t}}$ to present a standard chronology of Quercus frainetto Ten. in the rearch area.

\subsection{Time series analysis}

After tree - ring marking, ring widths were measured to the nearest 0,01 width a stereomicroscope and a LINTAB ${ }^{\mathrm{TM}}$ device (RINNTECH, Germany) with TSAP-Win ${ }^{\mathrm{TM}}$ (Version 0,55, 2003) software. Crossdating of tree-rings was carried out by using the TSAP software, wich was designed as a platform for the measurement and tree-rings time series analyses. The correlation between the different indirect methods is analysed with TSAP-Win Scientific ${ }^{\mathrm{TM}}$ a program for the measurement and analysis of tree-ring data [18]. Non-climatic trends were removed by using the autoregressive standardization (ARSTAN 198) program. To provide a new basis for removing non-climatic trends from tree ring data, regional growth curves (RGS s) have been recently used [19]. To obtain the RGS for the study site, the tree ring widths of all samples were averaged according to their cambial age. Moreover, the residual chronology was then used, which represented the maximum interannual climate variability. The quality of the chronologies was deemed sufficient if the expressed population signal (ESP) value of 0.88 was reached [20]. ESP was used to estimate the strength and reliability of the chronology through time [21]. The other growth indices were coefficient of parallel variation $=0.75, \mathrm{ESP}=0,86$, signal-tonoise $=0,74$ and mean sesitivity $=0.68$. After determining the growth indices, for each studied tree, the time series of tree -ring cronology was defined. Finally a chronology related to the studied trees was defined.

\subsection{Simulation of climatic parameters}

In this study, a multilayer perceptron - (MLP) net-work applied to simulate the climatic parameters. To estimate the climatic parameters during the past centuries, it was used from a feed-forward neural network and the LevenbergMarquardt (LM) learning algorithm. The tree-ring width and percepitation during the growth season were evaluted as inputs, and the precepitation of the growth season was adopted as the output. In the first stage, all data were normalized 
and divided into two classses: training data (70\% of all data), and testing data (30\% of all data). Neurosolutions software (Version 5.0-2011) was used as an ANN in the simulation. Consequently, the best network architecture for the simulation of climatic factors was found, by using a trail-and error method that was an MLP network with a sigmoid transfer function and an LM training technique. The number of hidden neurons was changed from 1 to 10 . Also, the trialand error method and sensitivity analysis were executed to select the appropriate input variables. There input petterns were evaluted, and their efficiencies (f) were evaluted and compared, an expressed in Eqs 2-4 :

$\mathrm{AI}=\mathrm{f}\left(\mathrm{W}_{\mathrm{t}}\right.$, where: AI-De Martonne aridity index, $\mathrm{W}_{\mathrm{t}}$ tree - ring width $(\mathrm{mm})$.

$P=f\left(W_{t}\right)$, where $P$ - annual precipitation $(\mathrm{mm})$.

$\mathrm{T}=\mathrm{f}\left(\mathrm{W}_{\mathrm{t}}\right)$, where $\mathrm{T}$-annual mean temperature $\left(\mathrm{C}^{0}\right)$.

Thee modelling process was started with one neuron is in one hidden layer and then progress (with increassing) until the performance of the test is satisfactory [22]. The ANN efficiency is evaluted by using the mean squared error (MSE) and the coefficient of determination $\left(R^{2}\right)$. Using a verified network for the study area for the period 1900-2015, the annual AI changes were simulated. With in the modelling process, the network input was annual tree ring, and the network outputs were the annual AI, P, and T. Finally, to evaluate the simulation accuracy, the simulated results were compared with the recoded values.

Table 1 Tree ring width- Wt- (Quercus frainetto Ten), annual precipitation (P), annual temperature (T), and the aridity index (AI)

\begin{tabular}{|c|c|c|c|c|}
\hline Year & $\mathbf{W}_{\mathrm{t}-}(\mathbf{m m})$ & $P(\mathbf{m m})$ & $\mathrm{T}\left({ }^{\mathrm{O}} \mathrm{C}\right)$ & AI \\
\hline 1960 & 1.55 & 298 & 13,4 & 12.84 \\
\hline 1961 & 2.79 & 317 & 12,7 & 14.10 \\
\hline 1962 & 2.35 & 345 & 13.3 & 14.96 \\
\hline 1963 & 2.41 & 371 & 12.9 & 16.39 \\
\hline 1964 & 3.03 & 328 & 13.8 & 14.03 \\
\hline 1965 & 2.30 & 373 & 13.1 & 16.33 \\
\hline 1966 & 2.88 & 353 & 13.3 & 15.31 \\
\hline 1967 & 2.68 & 360 & 12.5 & 16.19 \\
\hline 1968 & 2.24 & 320 & 12.9 & 14.11 \\
\hline 1969 & 3.25 & 367 & 13.7 & 15.65 \\
\hline 1970 & 2.45 & 310 & 13,9 & 13.08 \\
\hline 1971 & 2.26 & 328 & 13,3 & 14.22 \\
\hline 1972 & 1.95 & 330 & 13.1 & 14.33 \\
\hline 1973 & 2.33 & 357 & 13.8 & 15.16 \\
\hline 1974 & 2.17 & 303 & 14.7 & 12.36 \\
\hline 1975 & 2.34 & 317 & 14.2 & 13.21 \\
\hline 1976 & 3.26 & 343 & 13.6 & 14.68 \\
\hline 1977 & 3.45 & 335 & 13.7 & 14.27 \\
\hline 1978 & 2.88 & 288 & 13.8 & 12.20 \\
\hline 1979 & 3.09 & 351 & 13.7 & 14.96 \\
\hline 1980 & 2.28 & 309 & 14.4 & 12.77 \\
\hline 1981 & 1.95 & 377 & 13.2 & 16.44 \\
\hline
\end{tabular}




\begin{tabular}{|c|c|c|c|c|}
\hline 1982 & 2.88 & 256 & 14.9 & 10.34 \\
\hline 1983 & 1.75 & 150 & 13.8 & 6.20 \\
\hline 1984 & 2.55 & 278 & 14.1 & 11.62 \\
\hline 1985 & 1.25 & 151 & 13.1 & 6.52 \\
\hline 1986 & 2.58 & 295 & 14.1 & 12.39 \\
\hline 1987 & 2.65 & 278 & 13.9 & 12.72 \\
\hline 1988 & 2.91 & 329 & 13.3 & 14.26 \\
\hline 1989 & 2.04 & 245 & 13.8 & 10.35 \\
\hline 1990 & 1.16 & 139 & 13.2 & 5.95 \\
\hline 1991 & 3.25 & 330 & 13.4 & 14.24 \\
\hline 1992 & 2.82 & 338 & 12.9 & 14.93 \\
\hline 1993 & 3.26 & 258 & 13.4 & 11.10 \\
\hline 1994 & 2.12 & 265 & 14,2 & 11.02 \\
\hline 1995 & 1.69 & 199 & 13.6 & 8.50 \\
\hline 1996 & 1.77 & 197 & 13.8 & 8,33 \\
\hline 1997 & 2.34 & 286 & 14.01 & 12,01 \\
\hline 1998 & 1.74 & 216 & 13,80 & 8.96 \\
\hline 1999 & 2.33 & 296 & 13.60 & 12.43 \\
\hline 2000 & 2.88 & 314 & 14.55 & 12.65 \\
\hline 2001 & 0.94 & 143 & 12.75 & 7.01 \\
\hline 2002 & 2.68 & 342 & 13.4 & 14.77 \\
\hline 2003 & 2.85 & 378 & 14.1 & 15.85 \\
\hline 2004 & 2.45 & 292 & 14.2 & 12.16 \\
\hline 2005 & 2.35 & 370 & 14.4 & 15.26 \\
\hline 2006 & 2.03 & 218 & 13.8 & 9.20 \\
\hline 2007 & 1.92 & 277 & 13.8 & 12.72 \\
\hline 2008 & 1.63 & 195 & 14.9 & 8,01 \\
\hline 2009 & 2.70 & 306 & 13,8 & 12.97 \\
\hline 2010 & 2.82 & 228 & 13.8 & 9.54 \\
\hline 2011 & 1.90 & 248 & 14.9 & 10.01 \\
\hline 2012 & 1.80 & 216 & 14.3 & 8.92 \\
\hline 2013 & 1.53 & 203 & 13.4 & 8.70 \\
\hline 2014 & 1.60 & 221 & 14.1 & 9.20 \\
\hline 2015 & 1.74 & 236 & 13.7 & 10.02 \\
\hline
\end{tabular}

\section{Results}

Table 1- Shows some of the tree- ring widths and climatic factors. Statistical analysis was carried out with the SPSS software (Version 22.0, 2016) on climatic data (including T and P), It wass used from the Pearson correlation coefficients for the relationsships of $\mathrm{P}, \mathrm{T}$ and $\mathrm{AI}$ with the tree -ring chronologies. Table 2 - shows the results of correlations of the 
tree ring chronology with the climatic data (P, T, and AI). A significiant correlation of the tree ring with $\mathrm{P}, \mathrm{T}$, and AI-[23], was found. Also, the results showed that the tree ring was affected by P, T, and the climate classification (AI). The results from the analysis of variance idicated that tree-ring width was significantly (95\% probability) related to $P$ and $T$. According to results, effective factors in tree- ring width were $P$ and $T$. The time series of the tree-ring chronology and the annual aridity index during the study period are presented in Fig 2. Fig.3. presents the time series of the tree-ring chronology and the mean tree-ring widths during the last century. Also, the tree-rings significantly decreased over the last 60 years. The results of an ANN simulation during the training stage for the AI SIMULATION $\left(R^{2}=0,8\right)$. Are presented in Table 3. Based on Figure 4 an evaluation of the ANN efficiency in the climatic simulation during the validation (testing) stage was done comparing the simulated and the measured aridity indices $\left(\mathrm{R}^{2}=0,66\right)$. Figure 5 indicates the results the network efficiency evalution of the AI simulation.

Table 2 Person, s correlation between tree rings and annual precipitation (P), mean annual (T), and the aridity index (AI)

\begin{tabular}{|c|c|}
\hline \multicolumn{2}{|c|}{ Person, s correlation } \\
\hline $\mathrm{P}$ & 0,73 \\
\hline $\mathrm{T}$ & 0,27 \\
\hline $\mathrm{AI}$ & 0,72 \\
\hline
\end{tabular}

Table 3 Results of network training for simulating the aridity index using tree-ring width

\begin{tabular}{|l|c|c|}
\hline \multicolumn{1}{|c|}{ All runs } & Best network & Training \\
\hline Average of minimum MSEs & minimum MSE & 0,009 \\
\hline Average of final MSEs & final MSEs & 0,07 \\
\hline
\end{tabular}

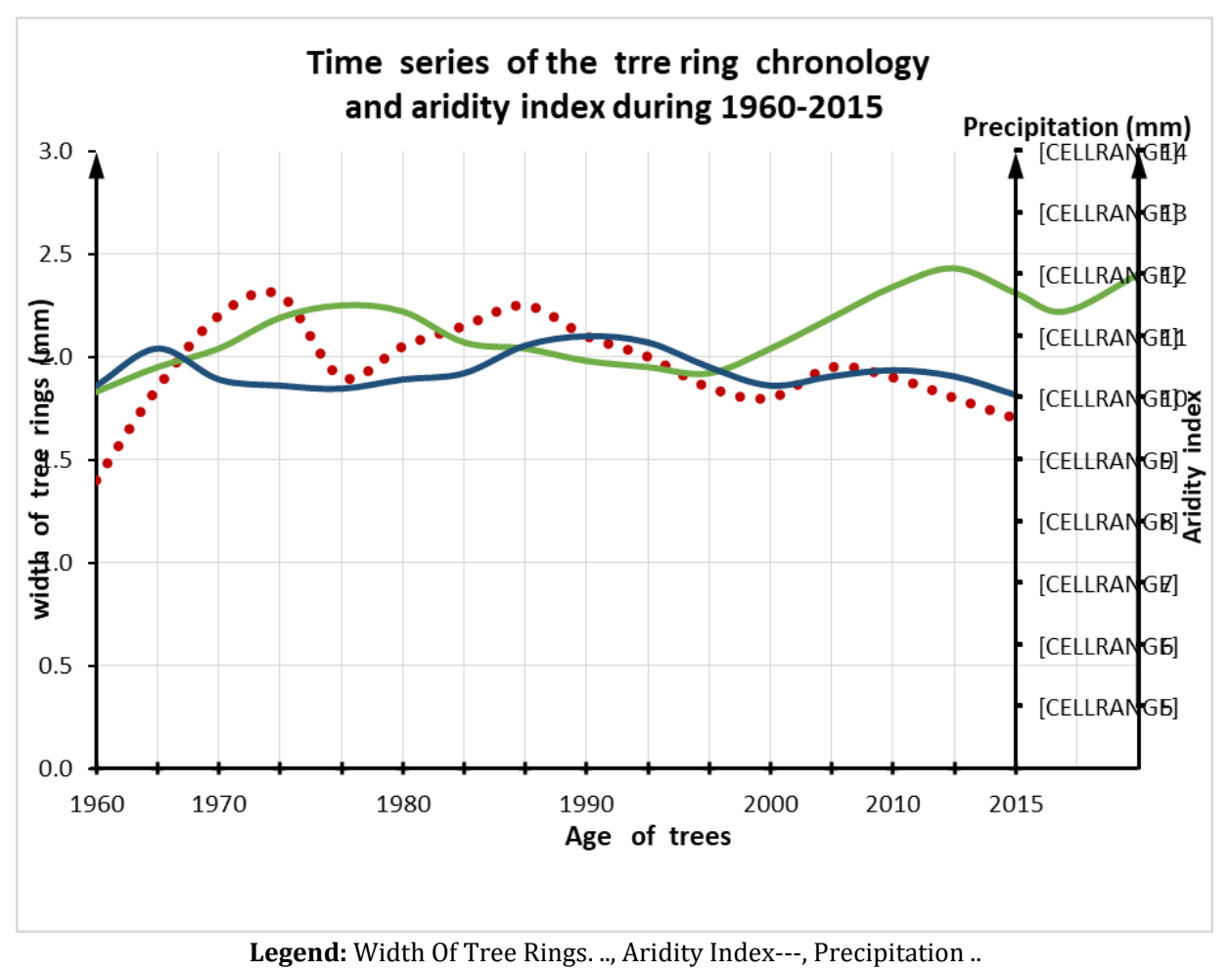

Figure 2 Time series of tree ring chronology and aridity index during 1960-2015 


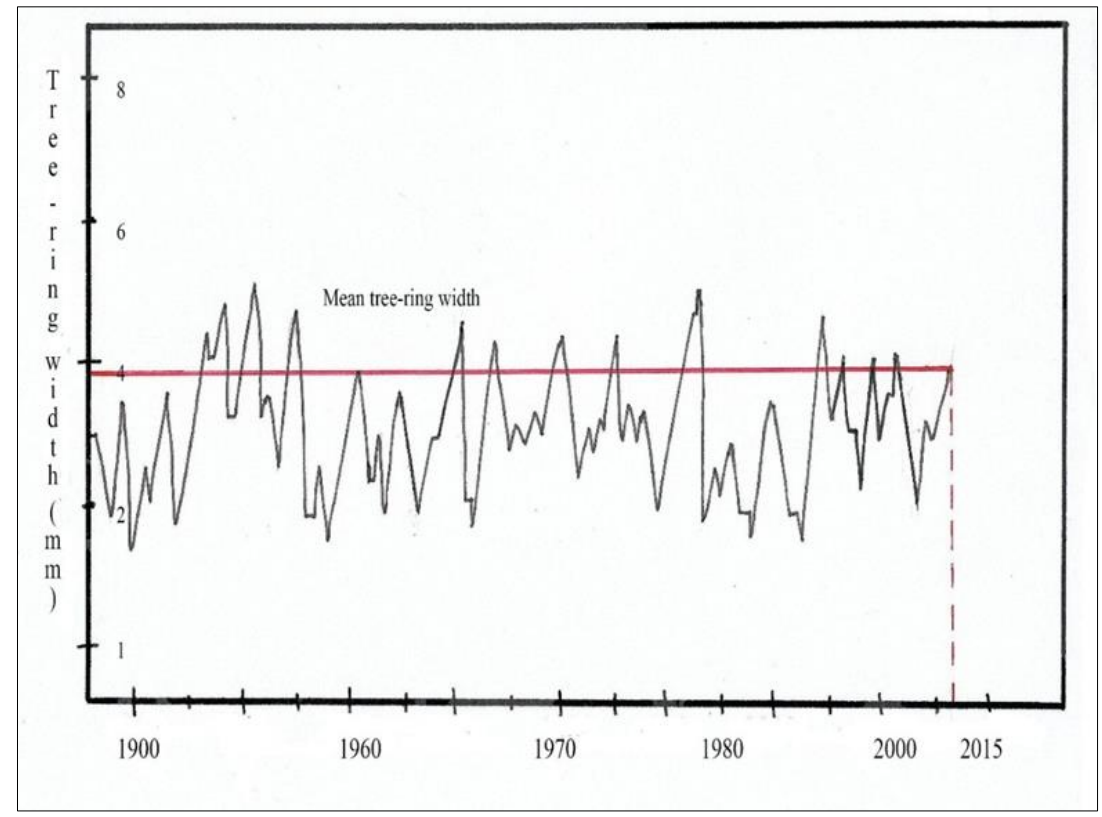

Figure 3 Time series of series the tree ring chronology and the mean tree-ring width in last century

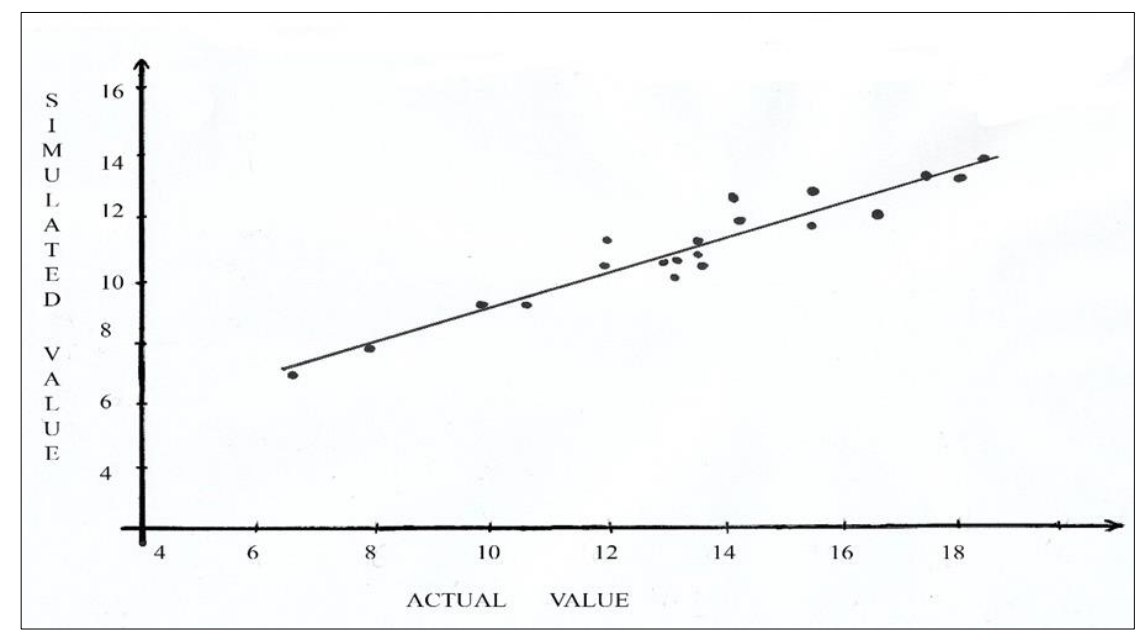

Figure 4 Comprasion between the simulated and the measured aridity index in the testing stage $\left(\mathrm{R}^{2}=8\right)$

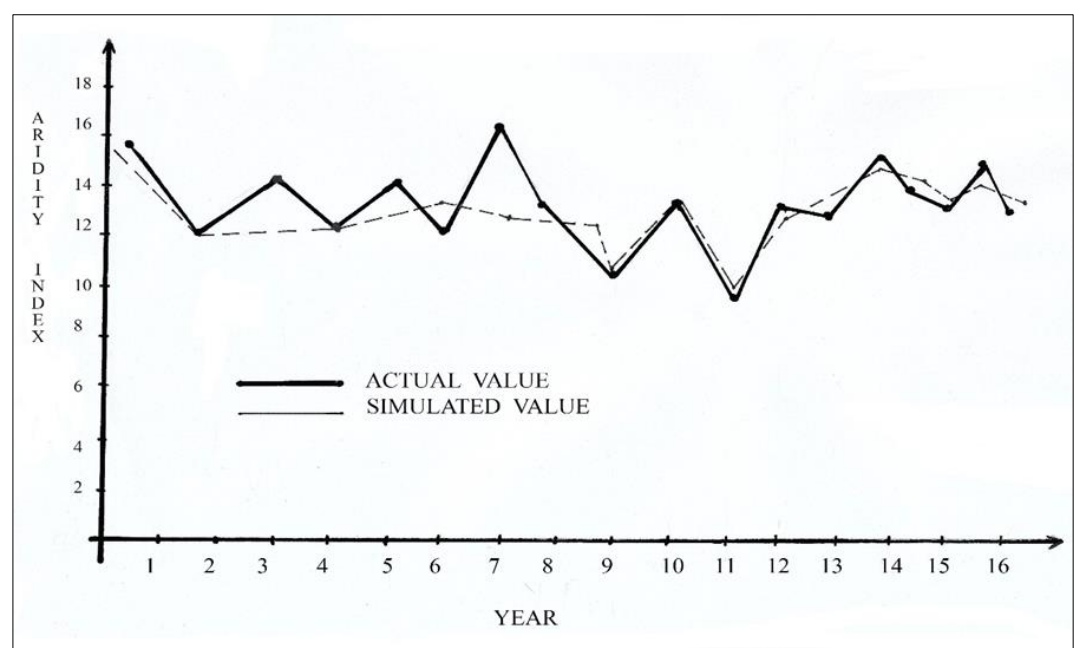

Figure 5 Comprasion between the simulated and the measured aridity index in the testing stage 
After network optimization, an efficiency evaluation for the testing stage was performed via a comprasion between the measured and the simuleted precipitation during the growing season. Moreover, past studies confirm ANN,s performance in other modelling studies [24]. Figure 6 shows the simulated AI during the last century. According to the simulated De Martonne index, the climate changed from semiarid to arid during the last century (Table 4).According to the results, the ability of an ANN in the simulation of the aridity index is at an accept-able level of accuracy. Based on these results, we found acceptable outcomes during the training stage. The optimum network stucture for precipitation simulation includes an MLP with the input tree rings, a sigmoid transfer function, the LM or momentum training techniques, and one neuron. A sigmoid transfer function and LM or momentum training techniques are some of the best selections for hydrologic modelling [25].

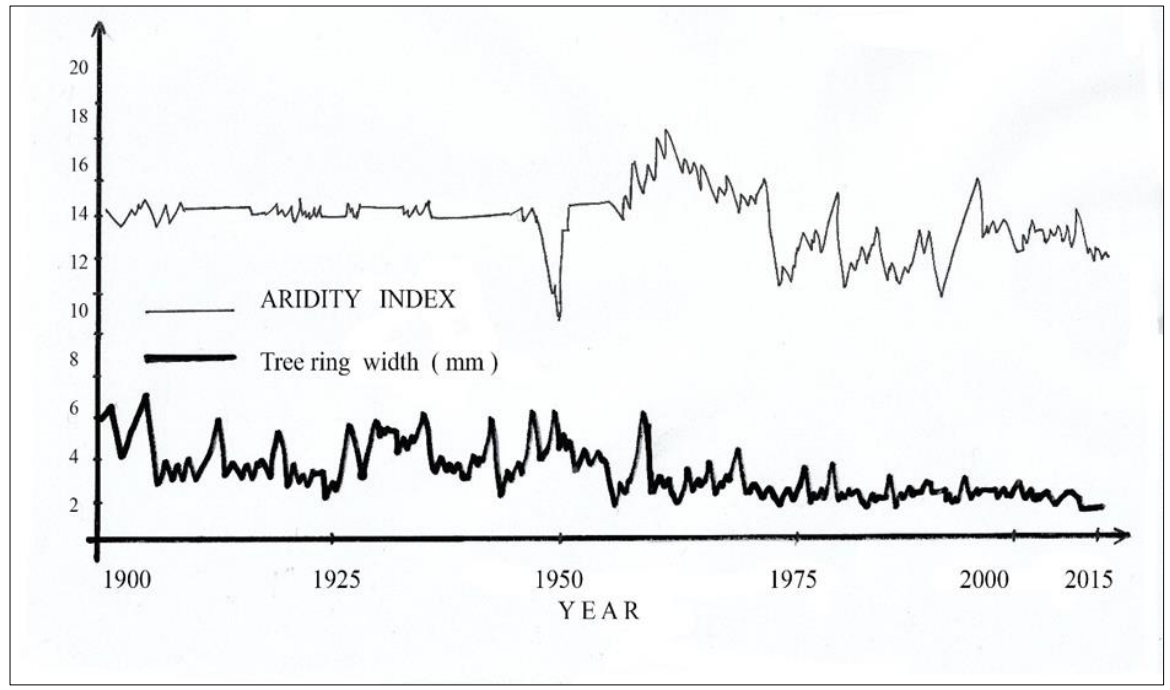

Figure 6 Aridity index simulated by using the verified neural network andd the measured tree ring in the last century

Figure 7 shows the annual precipitation during the last century as simulated by using dendroclimatology and an ANN. According to the results, the precipitation values in the study area decreased by about 100 mm over the last century.

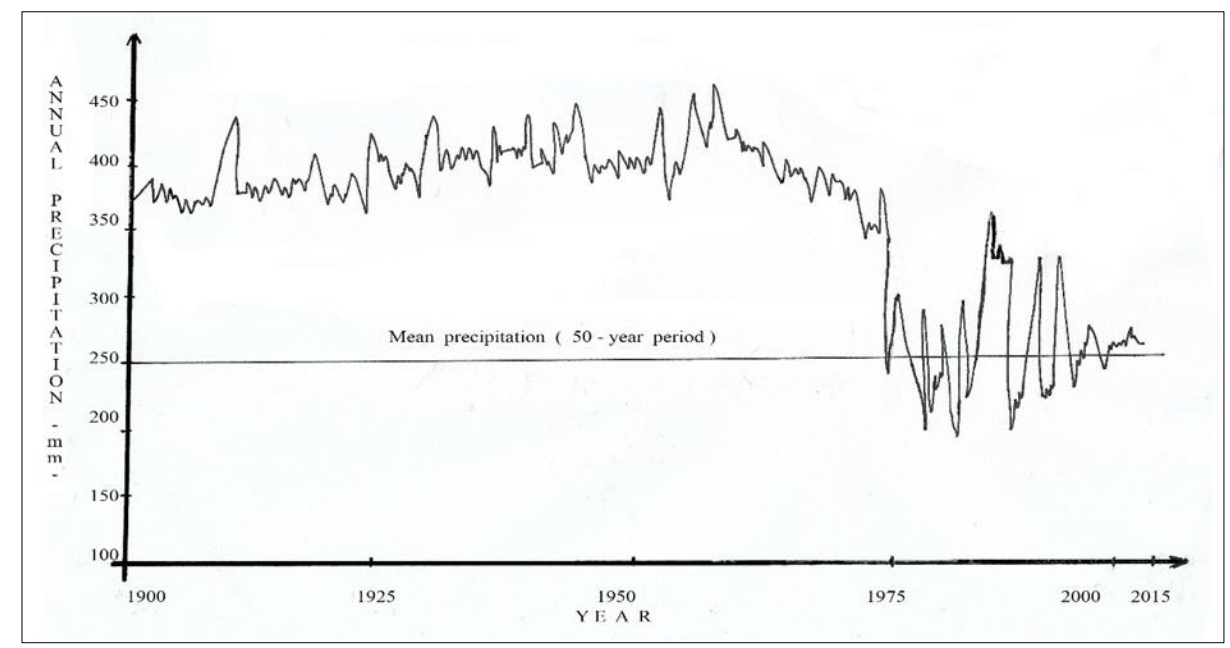

Figure 7 The simulated annual precipitation and the mean precipitation from Bojnourd meteorological station (50year period) in the last century

\section{Discussion}

One of the most commonly applied methode of evaluting climatic factor changes is the evalution of long-term records based on tree - ring analyses. To do this Quercus -chronologies were developed for the Šumadija region using different techniques, such as crossdating and standardization, and with aid of the ARSTAN software. These chronologies were correlated with climatic factors and climate changes were simulated based on the correlations. To found the variability 
of climate cconditions due to anthropogenic effects and other effective factors, there is a need to precisely date annual tree-ring chronologies over a long period [26].

Table 4 The changes in climate class, mean annual precipitation $(\mathrm{P})$ and mean annual temperature $(\mathrm{T})$ during the last century

\begin{tabular}{|l|l|l|l|l|}
\hline & P (mm) & T (C) & AI & climate classification \\
\hline 20th century & 355 & 12.9 & 16.2 & Mediterranean-(semi-arid) \\
\hline $\begin{array}{l}\text { Meteorological station } \\
\text { (the last 50 years) }\end{array}$ & 277 & 14.0 & 12.23 & arid \\
\hline
\end{tabular}

Therefore, to simulate the climate changes base on large-scale chronologies dating back, dendroclimatology and an ANN were applied together[27]. To evaluate the probable impacts of enabling-disabling tree rings, precipitation, temperature, and the arid ity index, some models were developed. Based on results, a suitable input variable for ANN in climatic simulation is tree-ring width. [28]. Thus we can prove the the high efficiency of the ANN and the present methodology (the integration of an ANN and dendroclimatology) in simulating climatic changes. [29]. The results showed that precipitation had a more significant relationshop with tree rings than did temperature, and the AI; however, using only the AI provided better results in the modelling of the climate index. Due to importance of the temperature factor under cold conditions, it is hardly likely to have been eradicted in a wetter regime [ 30 ]. Based on results, the best network structure for aridity index simulation is an MLP network with a sigmoid transfer function and the LM training technique and therefore an ANN based on the LM technique is an efficient structure for climatological simulations. Also, the results of the training stage showed that the MSE and the coefficient of determitation $\left(\mathrm{R}^{2)}\right.$ were 0,06 and 1,1 respectively. [31]. These results proved that the use of an ANN for the simulation of climatic factors has produced good results. During the the test stage, MSE and $\mathrm{R}^{2}$ were 0,08 and 0,9 respectively. We simulated the climatic factors for the period 1900- 2015 (P, T and AI). As shown in Figure 7- the annual precipitation values in the study area during the last century ranged 139 to $485 \mathrm{~mm}$. [32]. The annual mean temperature was from 13 to $17,5 \mathrm{C}^{0}$. This simulation can be used to define periods of drought. For example, during the last century, some drought period occurred. Based on the results, the most intense droughts occured 1955, 1970, and 1980 years.

\section{Conclusion}

The reconstruction accuracy for annual temperature was lower than that for precipitation because of two main reasons: first, there was a lesser fluctuation in annual temperature in the study area: and second, the studied trees in this research grew in the highlands and in an area of low temperature. In the mid-twentieth century,particulary from 1950-2015, notable climatic changes ossured in the Šumadija -region. By using tree ring-chronology and the AI, we found that the climate class in the study area changed from semiarid, and this trend in climatic changes continued. In Serbia climate change are present in precipitation is greater than in temperature. Also according to many researches, it has been reported from various studies that started after the late 20-century. We observed early climate changes in the Šumadija region-it is region central Serbia in the mid-twententh century, during which industrialization in the study area was intensified. The climatic reconstruction (P, T, and the AI) for period 1900-2015 showed a long term trend towared lesser precipitation and higher aridity over in last 115 years. What is clear from the results of this study is that the preciptation in the Šumadija region decreased in the mid-twentieth century and its climate changed from semiarid to arid period. Based $\mathrm{n}$ the above- mentioned dendroclimatology studiess, an intense drought in the study area was defined. If suitable tree species were selected in suitable environmental confitions for dendroclimatology studies, capability of debdroclimatology in modeling climate change would be proved. Topography, pedology, and tree physiology are the most important factors an determining the local distribution of trees under consideration. This study showed that the climate in the Šumadija (resarch regin) chnaged from semiarid- arid the last century.

\section{Compliance with ethical standards}

\section{Acknowledgments}

I would like to thank the Kragujevac forestry for making this research possible 


\section{Disclosure of conflict of interest}

Disclosure of conflict of interest the authors declare no conflict of interest.

\section{References}

[1] Barnett TP, Adam JC, Lettenmaier DP. Potential impacts of a warming climate on water availability in snowdominated regions. Nature no. 2005; 438: 303-309.

[2] Biondi F, Waikul K. Dendroclim. a C++ program for statistical calibration of climate signals in tree-ring chronologies. Comput Geosci. 2004; 30: 303-311.

[3] Williams AP, Allen CD, Macalady AK, Griffin D, Woodhouse CA, Meko DM, Swetnam TW, Rauscher SA, Seager R, Grissino-Mayer HD, Dean JS, Cook ER, Gangodagamage C, Cai M, McDowell NG. Temperature as a potent driver of regional forest drought stress and tree mortality. Nat. Clim-. Change. 2003; 3: 292-297.

[4] Briffa KR, Osborn TJ, Schweingruber FH, Jones PD, Shiyatov SG, Vaganov EG. Tree-ring width and density data around the Northern Hemisphere: Part 1, local and regional climate signals. Holocene. 2002; 12: 737-757.

[5] Brković D. Doktorska Disertacija, Vaskularna flora brdsko-planinskog područja severozapadne Srbije i Šumadije, ekološko-fitogeografska studija, Beograd. 2015; 45-50.

[6] Ault TR, S St George. The Mangitude of Decadal and Multidecadal Variability in North American Precipitation, Journal of Climate. 2010; 23(4): 842-850.

[7] David M, Meko DM, Woodhouse CA. Tree ring footprint of joint hydrologic, drought in Sacramento and Upper Colorado river basins western USA -Journal of hidrology. 2004; 196-213.

[8] Grace J, Allen S, Wilson C. Climate and meristem temperatures of plant communities near the tree-line, Oecologia. 1989; 79: 198-204.

[9] Christian-Smith J, MC Levy, PH Gleick. Maladaptation to drought: a case report from California, USA, Sustainability Science. 2014; 9017-9022.

[10] Loomis J, Koteen J, Hurd B. Economic and institutional strategies for adapting to water resource effects of climate change, in: Lewis Jr.., W.M. (Ed.), Water and Climate in the Western United States. University of Colorado Press, Boulder. 2003; 235-249.

[11] IPCC 2016-(International Panel on Climate Change)

[12] Eamus D, Jarvis PG. The direct efects of increase in the global atmospheric CO2 concentration on natural and commercial temperate trees and forests, Advanced in Ecological Research. 1989; 19: 21-45.

[13] Wullschleger SD, et al. On the potential for a CO2 fertilization effect on forest trees - an assessment of 58 controled exposure studies and estimates on the biotic growth factor. In Woodwell, G. M. (ed.), Biospheric Feedbacks in the Global Climate System: Will the Warming Speed the Warming?, Oxford University Press. 1990; 78-81.

[14] Sano M, Furuta F, Sweda T. Tree-ring-width chronology of Larix gmelinii as an indicator of changes in early summer temperature in east-central Kamchatka. J. For. Res. 2009; 14: 147-154.

[15] Vitas A. Tree rings chronology of Scotc-pine, (Pinus Silvestris L.) for Lithuania, Baltic Forestry. 2008; 14(2): 110115.

[16] RHMZ. Republic Hydrometeorological Institute of the Republic of Serbia - official institution. 2015.

[17] Daly CM, Halbleib JI, Smith WP, Gibson MK, Doggett GH, Taylor J. Curtis, PP Pasteris. Physiographically sensitive mapping of climatological temperature and precipitation across the conterminous United States, Int. J. Climatol. 2008; 28(15): 2031-2064.

[18] Sheppard RP. Identifying low-frequency tree-ring- variation. Tree-Ring Bull. 1991; 51: 29-38.

[19] St. George, S, Ault TR. The imprint of climate within Northern Hemisphere trees. Quat. Sci. Rev. 2014; 89: 1-4.

[20] Holmes RJ. Dendrochronology program library. Users manual. University of Arizona, Tucson. 1994; 34-36.

[21] Milovanović J. Degraded forest resources of Republic of Serbia,-zbornik radova,(konferencija), Beograd. 2010; 23-35. 
[22] Cook BIRL. Miller, R Seager. Amplification of the North American,,Dust Bowl,, drought throught, human-induced land degradation.Proceedings of the National Academy of Science. 2009; 106(13): 4997-5001.

[23] Funk C, A Hoell, D Stone. Examining the Contribution of the Observed Global Warming Trend to the California Droughts of 2012/13 and 2013/14, Bull Amer. Meteor. Soc. 2014; 95(9): 11-15.

[24] Bradley RS, Hughes MH, Mann ME. Comments on detection and attribution of recent climate change: a status report. Bull Am Meteorol Soc. 2000; 81: 115-118.

[25] St. George S. An overview of tree-ring width reords across the Northern Hemisphere, Quaternary Science Reviews. 2016; 95: 132-150.

[26] Stahle D, R Griffin, D Meko, M Therrell, J Edmondson, M Cleaveland, L Stahle, D Burnette, J Abatzoglou, K Redmond, et al. The Ancient Blue Oak Wood-lands of California: Longevity and Hydroclimate History, Earth Interactions. 2013; 17(12): 1-23.

[27] D’Arrigo R, Mashig E, Frank D, Wilson R, Jacoby G. Temperature variability. 2005.

[28] Watson E, Luckman BH. Tree-ring-based mass-balance estimates for the past 300 years at Peyto Glacier, Alberta, Canada. Quat. Res. 2004; 62: 9-18.

[29] Cayan DR, KT Redmond, L Riddle. ENSO and hydrologic extremes in the United States, Journal Climate. 1999; 12(9): 2881-2893.

[30] Christian-Smith J, MC Levy, PH Gleick. Maladaptation to drought: a case report from California, USA, Sustainability Science. 2014; 9017-9022.

[31] Svoboda MD, LeConte M Hayes, R Heim, K Gleason, J Angel, B Rippey, R Tinker, M Paalecki, D Stooksbury, et al. The drought monitor, Bulletin of the American Meteorological Society. 2002; 83(8): 1181-1190.

[32] Griffin D. How unusual is the 2012-2014 California drought, Department of Geography, Environment and Society, University of Minnesota.,Woods Hole, MA, USA. 2014; 34-42. 